\title{
Performance Evaluation of Water Supply Company (PDAM) in Depok
}

\author{
Muhammad Haekal and Praptiningsih
}

\begin{abstract}
The aim of this study to evaluate the performance of PDAM Tirta Asasta Depok City in 2017-2018. In this research, using qualitative methods as a result of analysis by the phenomenological approach. This study refers to the Board of Water Supply System Improvement Implementation (BPPSPAM) No. 002/2010 On PDAM Performance Assessment as an indicator of performance appraisal. The results of this study indicate that PDAM Tirta Asasta Depok obtain ratings by category "Healthy" in 2017 and 2018. While it can be categorized as healthy, there are some indicators that need to get the company's attention in this regard: the financial aspects of indicators Return On Equity (ROE) and operating ratio. Aspects of service with technical indicators of service coverage, customer growth as well as domestic water consumption. Operational aspects of the indicators of production efficiency, Non Account Water (NRW). As well as aspects of human resources with the ratio of employee training load. Additionally, PDAM Tirta Asasta Depok on the assessment of drinking water quality requirements show has not been optimal. Therefore, management of PDAM Tirta Asasta Depok required to assign priority handling in improving corporate performance.
\end{abstract}

Keywords-Performance Evaluation, Assessment Aspects, Performance Indicators.

\section{INTRODUCTION}

Water Supply Company (PDAM) is one of the Regional Owned Enterprises (enterprises) that provide clean water distribution to the public. In general, the taps are in every city, district and province in Indonesia. PDAM formed has the aim of providing services to people in need of clean water that is in accordance with the Rules and Regulations, as well as increase revenue (PAD). The problems being experienced by PDAM is the loss experienced by a large enough company that caused the leakage of water into the cause of decreasing revenues. Water leakage rate is relatively high in the range of $30-40 \%$ of water distributed (Lamba and Hartono, 2015). The water leak caused the amount of water received by consumers reduced compared to the amount produced by the installation. The high level of water leakage in the water utilities into one of the factors decreasing performance of the company.

The company's success in managing the water supply system is measured based on an assessment of the performance. Based on this, the assessment of the performance of taps governed by Interior Minister Decree

Published on March 21, 2020

Muhammad Haekal, Economics and Business Faculty Universitas Pembangunan Nasional Veteran Jakarta, Indonesia.

(e-mail: haekalhilman@gmail.com)

Praptiningsih, Economics and Business Faculty Universitas Pembangunan Nasional Veteran Jakarta, Indonesia.
No. 47 of 1999, dated May 31, 1999 and the Chairman of Board of Water Supply System Improvement (BPPSPAM) No. 002/2010 On PDAM Performance Assessment. BPPSPAM is a governmental institution established based on Presidential Decree No. 90 Year 2016 BPPSPAM have the duty to revitalize the development of drinking water supply system, and assist the government in an effort to improve the implementation of Drinking Water System Providers (SPAM) carried by one of the enterprises.

Based on the above arguments, this study aims to evaluate the performance of PDAM Kota Depok in 2017 and 2018 by the Chairman of BPPSPAM No. 002/2010 On PDAM Performance Assessment. accounting firms that was involved in the case (www.pppk.kemenkeu.go.id).

\section{LITERATURE REVIEW}

\section{A. Theory Perspective}

Performance measurement according to the Interior Minister Decree No. 47 of 1999 is quite good with financial aspects, aspects of assessment, operational aspects, and administrative aspects. But needed improvement in several indicators, the operational costs are higher than the national income (Andriani, 2018).

Furthermore, the study refers to the Board of Water Supply System Improvement Implementation (BPPSPAM) No. 002/2010 On PDAM Performance Assessment as an indicator of performance appraisal. Aspects of performance assessment covers the financial aspects, aspects of service, operational aspects, and aspects of human resources.

\section{B. Performance Assessment}

There are several studies that appropriate research to support this study are based on a research topic, the previous studies presented in this study is related to the assessment of company's performance. Performance is the implementation of activity in realizing the objective, vision, mission and goals in the organization (Aswar, 2019). There is some previous research related to water management and their impact on the performance. For example, Adriani (2018) PDAM performance-based appraisal according to the Interior Minister Decree No. 47 of 1999. Found that needed to improvement operating costs that still higher than the income of the national water. In line with research in Surabaya city and Madiun (Sulthon, 2017; Amah, 2017).

Furthermore, Pradityo (2016) PDAM Tirta Perwitasari Purworejo in 2013 and 2015 have been performing well, as evidenced by the performance values above 2.8 and has received the title "Healthy" is based on 18 criteria of performance indicators BPPSPAM. Aso, the found that to improve its performance is limited sources of raw water to produce drinking water base and rates are still low. Similarly, in Malinau city (Prakoso, Jonathan \& Lau, 2013).

Performance assessment also measured 5 aspects by previous studies which is operational, financial, 
administration, services and human resources in SPAM low performance (Lolon, 2017; Minarti, 2017; Shia, Sandhyavitri \& Fauzi, 2014). Meanwhile, According Syafitri (2013) using two (2) indicators of the main indicators and additional indicators. On key indicators, namely, profitability, liquidity and solvency. The results found that the financial performance of PDAM Palembang into the healthy group. Sidoarjo regency using financial perspective, although not be separated from non-financial perspective (Prasetya, 2012).

According to Ahmad \& Prasher (2010) dynamic simulation model was developed to South Florida in capturing the relationship between water availability and towns, farms, and the potential of the aquatic environment. The performance criteria used is reliability, resilience, and vulnerability that are used to measure the success of the policy. Furthermore, Galaon, Petre, Iancu, Cruceru, Niculescu, Chiriac, Puin, Mihalache (2017) A new sensitive and selective LC-MS/MS method with positive electrospray ionization was developed to detect seven cytostatic drugs and one metabolite from municipal waste water. The method was tested on four waste water samples from a WWTP plant in Bucharest, but none of the targeted cytostatic drugs were found above detection limit.

Study by Renzetti and Dupont (2008) this study extends the multistage procedure set out in Fried et al (1999) to examine the importance of environmental factors when assessing the technical efficiency of water agencies. However, following Simar and Wilson's (2007) critique of multistage efficiency analyzes, the paper uses a bootstrapping approach in order to have consistent inference. The main findings are that environmental factors explain some of the observed variation in efficiency scores and that water agencies' relative efficiency scores are changed substantially after controlling for environmental factors. In India with using analytical tool to measure technical efficiency. Found that strengthen the hypothesis that functional autonomy in management leads to better performance o the water utilities (Gupta, Sarangi, 2012; Yadav, Singh, Shah \& Gamit 2014). In South Africa, Wegelin, WA, and Jacobs, HE (2013) conducted study the implementation of water conservation and water demand management (WC/WDM) at municipal level has been inadequate for many years, despite South Africa being one of the driest countries in the world. Municipalities often fail to realise that most WC/WDM activities will pay for themselves and that financial institutions will fund these projects if a proper business case could be compiled. Ironically municipalities have complained that they are unable to obtain funding while most financial institutions complain that they cannot find bankable projects because of the poor quality of the applications and strategies. This guideline provides a simple and pragmatic approach to the development of a WC/WDM strategy and business plan which will enable municipalities to plan, obtain funding, implement and ensure the overall sustainability of water resources in the municipality.

\section{Schema of Performance Assessment and Performance Process Flow}

PDAM performance assessment is a way of measuring process, project, or product in the taps to provide an overview of management activities PDAM success rate in one year (Bhakti, 2018). PDAM performance assessment is an attempt to measure the production process so that it becomes a product. In addition, PDAM performance assessment aims to provide an overview of information related to the successful management within a period of one financial year.

Broadly speaking picture PDAM performance evaluation activities Years 2017 and 2018 can be carried out by the following steps: Inventory data is a step in data collection. Data adjusted to the aspect of the performance assessment PDAM. Verification, Validation, and Updating a step in getting the latest data validated and verified in order to obtain an accurate evaluation result. The data has been collected is inserted into the formula calculation of performance indicators. The calculation of the value of performance indicators based on standard values contained in each of the indicators by obtaining the total value of the performance. Performance Status Determination is done by comparing the sum of the values obtained with the performance criteria have been established, with criteria: performance Health with a total value of $>2.8$, less healthy with a total value of 2.2 to 2.8 performance, and pain with a total performance of $<2.2$. Deviation analysis of performance indicators on aspects of assessment, carried out an analysis of the performance indicators contained in the aspects of assessment by comparing 2017 and 2018. After analysis, then provided recommendations for improvements on performance indicators that are experiencing a decline in 2018.

PDAM performance assessment based on rules BPPSPAM No. 002/2010 On PDAM Performance Assessment using a balanced scorecard, which is the performance appraisal which uses the principle of score considering the characteristics. There are differences in the weight percentage of judgments contained in every aspect of performance appraisal which is; aspect score indicators (financing $=0.25$, service $=0.25$, and human resources $=0.15$ ), meanwhile the category of value (healthy $>2.8$, less healthy 2.2-2.8, and pain $<2.2$ ).

Based on the details of above explanation as follows:

a. Financial aspect. In this aspect demonstrates the company's ability role in profit and streamline other operational activities. Financial aspects have three (3) the assessment indicators, namely, profitability, liquidity, and solvabilitias. Based on these indicators can be seen in Table 1.

TABLE 1. INDICATORS FINANCIAL ASPECTS

\begin{tabular}{|c|c|c|c|}
\hline $\begin{array}{c}\text { PERFORMANCE } \\
\text { INDICATORS }\end{array}$ & WEIGHT & STANDARD & $\begin{array}{c}\text { VALUE } \\
\text { STANDARD }\end{array}$ \\
\hline \multicolumn{4}{|l|}{ PROFITABILITY } \\
\hline \multirow[t]{5}{*}{ a. Return On Equity } & 0.05 & $\geq 10(\%)$ & 5 \\
\hline & & $7-<10(\%)$ & 4 \\
\hline & & $3-<7(\%)$ & 3 \\
\hline & & $0-<3(\%)$ & 2 \\
\hline & & $<0(\%)$ & 1 \\
\hline \multirow[t]{5}{*}{ b. Operating ratio } & 0.05 & $\leq 0.5$ & 5 \\
\hline & & $>0.5$ to 0.65 & 4 \\
\hline & & $>0.65$ to 0.85 & 3 \\
\hline & & $>0.85$ to 1.0 & 2 \\
\hline & & $>1.0$ & 1 \\
\hline \multicolumn{4}{|l|}{ LIQUIDITY } \\
\hline \multirow[t]{5}{*}{ a. Cash ratio } & 0.05 & $\geq 100(\%)$ & 5 \\
\hline & & $80-<100(\%)$ & 4 \\
\hline & & $60-<80(\%)$ & 3 \\
\hline & & $40-<60(\%)$ & 2 \\
\hline & & $<40(\%)$ & 1 \\
\hline
\end{tabular}




\begin{tabular}{lclc}
\hline $\begin{array}{l}\text { PERFORMANCE } \\
\text { INDICATORS }\end{array}$ & WEIGHT & STANDARD & $\begin{array}{c}\text { VALUE } \\
\text { STANDARD }\end{array}$ \\
\hline b. effectiveness & \multirow{2}{*}{0.05} & $\geq 90(\%)$ & 5 \\
Billing & & $85-<90(\%)$ & 4 \\
& $80-<85(\%)$ & 3 \\
& & $75-<80(\%)$ & 2 \\
& & $<75(\%)$ & 1 \\
\hline SOLVENCY & \multirow{2}{*}{0.03} & $\geq 200(\%)$ & 5 \\
& & $170-<200(\%)$ & 4 \\
& & $135-<170(\%)$ & 3 \\
& & $100-<135(\%)$ & 2 \\
& $<100(\%)$ & 1 \\
\hline
\end{tabular}

b. Aspects of Care. In this aspect aims to describe the level of a company's ability to meet customer needs, based on five (5) indicators can be seen in Table 2.

TABLE. 2 INDICATORS ASPECTS OF CARE

\begin{tabular}{|c|c|c|c|}
\hline $\begin{array}{l}\text { PERFORMANCE } \\
\text { INDICATORS }\end{array}$ & WEIGHT & STANDARD & $\begin{array}{l}\text { VALUE } \\
\text { STANDARD }\end{array}$ \\
\hline \multirow[t]{5}{*}{$\begin{array}{l}\text { Scope of Technical } \\
\text { Services }\end{array}$} & \multirow[t]{5}{*}{0.05} & $\geq 80(\%)$ & 5 \\
\hline & & $60-<80(\%)$ & 4 \\
\hline & & $40-<60(\%)$ & 3 \\
\hline & & $20-<40(\%)$ & 2 \\
\hline & & $<20(\%)$ & 1 \\
\hline \multirow[t]{5}{*}{$\begin{array}{l}\text { Subscriber Growth } \\
\text { (\% Per Year) }\end{array}$} & \multirow[t]{5}{*}{0.05} & $\geq 10(\%)$ & 5 \\
\hline & & $8-<10(\%)$ & 4 \\
\hline & & $6-<8(\%)$ & 3 \\
\hline & & $4-<6(\%)$ & 2 \\
\hline & & $<4(\%)$ & 1 \\
\hline \multirow[t]{5}{*}{$\begin{array}{l}\text { Level Complaint } \\
\text { Resolution }\end{array}$} & \multirow[t]{5}{*}{0,025} & $\geq 80(\%)$ & 5 \\
\hline & & $60-<80(\%)$ & 4 \\
\hline & & $40-<60(\%)$ & 3 \\
\hline & & $20-<40(\%)$ & 2 \\
\hline & & $<20(\%)$ & 1 \\
\hline \multirow[t]{5}{*}{$\begin{array}{l}\text { Water Quality } \\
\text { Customers }\end{array}$} & \multirow[t]{5}{*}{0.075} & $\geq 80(\%)$ & 5 \\
\hline & & $60-<80(\%)$ & 4 \\
\hline & & $40-<60(\%)$ & 3 \\
\hline & & $20-<40(\%)$ & 2 \\
\hline & & $<20(\%)$ & 1 \\
\hline \multirow[t]{5}{*}{$\begin{array}{l}\text { Domestic Water } \\
\text { Consumption }\end{array}$} & \multirow[t]{5}{*}{0.05} & $\geq 30$ (m3 / month) & 5 \\
\hline & & $25-<30$ (m3 / month) & 4 \\
\hline & & $20-<25$ (m3 / month) & 3 \\
\hline & & $15-<20(\mathrm{~m} 3 /$ month $)$ & 2 \\
\hline & & $<15$ (m3 / month) & 1 \\
\hline
\end{tabular}

c. Operational aspects. In this aspect aims to determine the effectiveness of production and distribution, water loss rate, and the continuity of water services. Operational aspects have 5 (five) indicators can be seen in Table 3 .
TABLE 3. INDICATORS OF OPERATIONAL ASPECTS

\begin{tabular}{|c|c|c|c|}
\hline $\begin{array}{l}\text { PERFORMANCE } \\
\text { INDICATORS }\end{array}$ & WEIGHT & STANDARD & $\begin{array}{l}\text { VALUE } \\
\text { STANDARD }\end{array}$ \\
\hline \multirow[t]{5}{*}{ Production efficiency } & 0.07 & $\geq 90(\%)$ & 5 \\
\hline & & $80-<90(\%)$ & 4 \\
\hline & & $70-<80(\%)$ & 3 \\
\hline & & $60-<70(\%)$ & 2 \\
\hline & & $<60(\%)$ & 1 \\
\hline \multirow[t]{5}{*}{ Water Not NRW } & 0.07 & $\leq 25(\%)$ & 5 \\
\hline & & $>25-30(\%)$ & 4 \\
\hline & & $>30-35(\%)$ & 3 \\
\hline & & $>35-40(\%)$ & 2 \\
\hline & & $>40(\%)$ & 1 \\
\hline \multirow[t]{5}{*}{ Operating Hours Service } & 0.08 & $21-24$ & 5 \\
\hline & & $18-21$ & 4 \\
\hline & & $16-18$ & 3 \\
\hline & & $12-16$ & 2 \\
\hline & & $<12$ & 1 \\
\hline \multirow[t]{5}{*}{$\begin{array}{l}\text { Water Pressure on } \\
\text { Customer Connection }\end{array}$} & 0.065 & $\geq 80(\%)$ & 5 \\
\hline & & $60-<80(\%)$ & 4 \\
\hline & & $40-<60(\%)$ & 3 \\
\hline & & $20-<40(\%)$ & 2 \\
\hline & & $<20(\%)$ & 1 \\
\hline \multirow[t]{5}{*}{$\begin{array}{l}\text { Water Meter Replacement } \\
\text { Customers }\end{array}$} & 0.065 & $\geq 20(\%)$ & 5 \\
\hline & & $15-<20(\%)$ & 4 \\
\hline & & $10-<15(\%)$ & 3 \\
\hline & & $5-<10(\%)$ & 2 \\
\hline & & $<5(\%)$ & 1 \\
\hline
\end{tabular}

d. Aspects of human Resources. In this aspect aims to determine the level of learning and innovation in the management of the taps. HR aspects have three (3) indicators which can be seen in Table 4 .

TABLE 4. INDICATORS OF HR

\begin{tabular}{|c|c|c|c|}
\hline $\begin{array}{l}\text { PERFORMANCE } \\
\text { INDICATORS }\end{array}$ & WEIGHT & STANDARD & $\begin{array}{c}\text { VALUE } \\
\text { STANDARD }\end{array}$ \\
\hline \multirow{5}{*}{$\begin{array}{l}\text { The ratio of Total } \\
\text { Employees / } 1,000 \\
\text { Customers }\end{array}$} & \multirow[t]{5}{*}{0.07} & $\leq 6$ people $)$ & 5 \\
\hline & & > 6-8 (People) & 4 \\
\hline & & $>8-10$ (People) & 3 \\
\hline & & $>10-12$ (People) & 2 \\
\hline & & > 12 (People) & 1 \\
\hline \multirow[t]{5}{*}{$\begin{array}{l}\text { The ratio of } \\
\text { Employee Training }\end{array}$} & \multirow[t]{5}{*}{0.04} & $\geq 80(\%)$ & 5 \\
\hline & & $60-<80(\%)$ & 4 \\
\hline & & $40-<60(\%)$ & 3 \\
\hline & & $20-<40(\%)$ & 2 \\
\hline & & $<20(\%)$ & 1 \\
\hline \multirow{5}{*}{$\begin{array}{l}\text { Training Expenses } \\
\text { Charges Against } \\
\text { Employees }\end{array}$} & \multirow[t]{5}{*}{0.04} & $\leq 10(\%)$ & 5 \\
\hline & & $7.5-<10(\%)$ & 4 \\
\hline & & $5-<7.5(\%)$ & 3 \\
\hline & & $2.5-<5(\%)$ & 2 \\
\hline & & $<2.5(\%)$ & 1 \\
\hline
\end{tabular}

Source: Performance Assessment taps by BPPSPAM 


\section{Research Methodology}

The qualitative method used in this study, due to the paradigm shift in looking at a phenomenon that occurs in companies that are likely to change. The cause of this phenomenon changes among which, the environmental factors that can affect a change in the company's phenomenon.

The paradigm used in this study is the interpretive paradigm, because to know social reality that occurs in the study of viewpoint and understanding of the subject of this study. Furthermore, the phenomenological approach used to describe and determine the understanding of the experience that is consciously experienced by some individuals, in this case is an employee in the neighborhood PDAM Depok city in charge of implementing the management and distribution of water in Depok.

This research conducted in PDAM Tirta Asasta Depok City which is located at the Legong Raya No. 1 , Depok 2 Tengah, Sukmajaya, Mekar Jaya district. Sukmajaya, Depok, West Java 16411. The subjects were informant or informants in this study data sources is PDAM Kota Depok. For this purpose, supported by the expertise of researchers have gone through the course of Internal Audit, Corporate Governance, and Financial Accounting. The data used in this study consisted of informants as a source of primary data sources and sources of printed materials or electronic media as a secondary data source.

Source informants as a source of primary data in this study are employees within PDAM Tirta Asasta Depok authorities in running the company's operations, Directors, Financial Manager / Operational, the Senior Manager of Internal Audit Unit (Key Informant I), the Senior Manager of Human Resources (Key Informant II), and other employees, Researchers set of key informants and supporters to get the data related with constraints in implementing policies to support the operations of the company SOPs.

Researchers used a list of answers as the basis for obtaining information. Subsequently, author conducted elimination of informants answer by focusing on the topics studied. To determine the validity of the information obtained, the researchers validate the answers, labeling of the answers and themes.

\section{Results AND Discussion}

Based on the decision BPPSPAM No. 002/2010 On PDAM Performance Assessment, there are four (4) aspects of performance assessment, the financial aspect, service, operational, and human resources. Here is the analysis obtained from each indicator as follows:

a. Financial aspect

The financial aspects of performance assessment in 2017 and 2018 shows that in 2018 the financial aspect ratings on indicators of liquidity and solvency have obtained the optimal value with a value of 5 (five). While the profitability indicators do not meet the optimal value. This looks at the indicators of the operating ratio in 2018 decreased compared to 2017 is equal to 0.055 . This suggests that non-optimal operating revenue and operating expense efficiencies. b. Aspects Of Care

The performance assessment aspect of the service in 2017 and 2018 shows that in 2018 the service aspect ratings on indicators of the level of complaints resolution, and water quality has gained customers optimal value with the value of 5 (five).

Meanwhile, there are several indicators that need to get the company's attention, which is the scope of the technical service, customer growth, and domestic water consumption.

c. Operational Aspects Operational aspects of performance assessment in 2017 and 2018 shows that in 2018 the operational aspects of the 5 assessment an indicator that the company is not optimal in implementing Operational. It can be seen on the indicator decreased production efficiency which is equal to 0.070 .

d. Aspects Of Human Resources

The performance assessment aspect of HR it can be seen that the votes of the three indicators shown enough in implementing aspects of optimal company human resources. This is evident from the three (3) indicators, only one indicator that has not reached the optimal value, the training load on personnel expenses.

\section{COnClusion, Limitations And Recommendations}

The purpose of this study was to evaluate the performance of PDAM Depok city in 2017-2018. This evaluation consists of aspects of performance based on BPPSPAM Decree No.002 / 2010 on PDAM Performance Assessment. The results of this study showed that of the four aspects of performance assessment tends to increase over the previous year, but in the aspect of service with coverage of technical indicators decreased compared to the previous year. That is, not optimal company in improving its technical services coverage.

The suggestion for future study is the result of performance evaluation has been carried out, indicates that there are several indicators of every aspect of performance assessment needs to get the company's attention. In this case, the indicators need to get the company's attention is an indicator that has not gained votes in regarding optimal weight rating set by BPPSPAM. Based on the results of this study can be a reference for the implementation done by the company in order to improve the company's performance. The next study add the research samples so that a better result can be obtained.

\section{REFERENCES}

Adriani. (2018). Financial Performance Evaluation on Regional Water Company: Empirical Study on Bantimurung Tirta Maros. Journal Application Management, Economics and Business, 3 (1), 26-33.

Ahmad, S., Prashar, D. (2010). Evaluation Municipal Water Conservation Policies Using a Dynamic Simulation Model: Studi Empiris Florida Selatan, Jurnal Water Resour Manage, 24, 3371-3395.

Amah, N, (2017). Influence of Organizational Culture on Employee Performance: Empirical Study of PDAM Tirta Sari Taman Madiun. Journal of Accounting and Education, 6 (1).

Aswar, K (2019). Financial performance of local government in Indonesia. European Journal of Business and Management Research. 4 (6). 1-6.

Decree of the Minister of Interior of the Republic of Indonesia Number 47 of 1999. (1999). On Guidelines for Assessment of Regional Water Company Performance. 
Galaon, T., Petre, J., Iancu, VI, Cruceru, L., Niculescu, M., Chiriac, FL, Puiu, D.M, \& Mihalache, M. (2017). In Detection Of Cytostatic Drugs And Their Municipal Waste Water Transfer To Surface Water. International Symposium "The Environment and The Industry", SIMI 2017, Proceedings Book, DOI:http://doi.org/10.21698/simi.2017.0029,

Gupta, S., Kumar, S., \& Sarangi, GK (2012). Measuring the Performance of Water Service Providers in Urban India: Implication fo Managing Water Utilities Act: Empirical Study of India. Water policy, 14, 391-408.

Improvement Agency Implementation of Water Supply System. (2010). PDAM Performance Assessment. AccessedAugust 10th, 2019, from http://sim.ciptakarya.pu.go.id/bppspam/list category / 19

Improvement Agency Implementation of Water Supply System. (2017). PDAM Performance Assessment. AccessedOctober 7th, 2019, from http://sim.ciptakarya.pu.go.id/bppspam/assets/assets/upload/ BUKU Lap Kinerja PDAM 2017 FA.pdf.

Improvement Agency Implementation of Water Supply System. (2017). PDAM Performance Assessment Technical Guidelines. Accessed10 November 2019, from http://bppspam.com:8090/forum/assets/frond/upload/Petunjuk\% 20Teknis\%20Penilaian\%20Kinerja\%20PDAM.pdf.

Indonesian Presidential Regulation No. 90 of 2016. (2016). About organizing Improvement Agency Drinking Water System Provider.

Lamba, AA, Hartono, DM (2015). Clean Water Network Optimization Distribus PDAM Tirta Kahuripan Services Branch 2 Depok, Journal of Civil Engineering, Faculty of Engineering, University of Indonesia.

Lolon, A. (2017). PDAM Performance Assessment Study of the city of Palangkaraya: Empirical Study on PDAM Palangkaraya, Regional Development and State Journal, 13 (3), 269-285.

PDAM Tirta Asasta. (2018). Performance Audit Report PDAM Tirta Asasta, Depok.

PDAM Tirta Asasta. (2017). Performance Audit Report PDAM Tirta Asasta, Depok

Pradityo, A. (2016). Analysis of Regional Water Company Performance: Empirical Study on PDAM Tirta Perwitasari Purworejo, Journal of Economics and Business. 1-26.

Prakoso, B.I, Jonathan, R., \& Lau, E.A. (2013). Analysis of Regional Water Company Performance: Empirical Study on Malinau District, Journal of Economics and Business. 1-7.

Regulation of the Minister of Health of the Republic of Indonesia No. 492 / Menkes / PER / IV / 2010. (2010). of Drinking Water Quality Requirements.

Syafitri, Y. (2013). Soundness Evaluation of Financial Performance in Regional Water Company. Journal of Competitive, Palembang. 2 (1), 74-89

Prasetya, A.P. (2012). Performance Analysis PDAM Tirta Delta District Sidoarja Using Financial and Non-Financial Perspective: Empirical Study on PDAM Delta Tirta Sidoarja District, Student Scientific Journal of Accounting, 1 (1), 73-78.

Renzetti, S., \& Dupont, D. (2008). Measuring The Techincal Efficiency of Municipal Water Suppliers: The Role of Environmental Factors, Land Economics, 8, 1-23.

Wegelin, W.A, \& Jacobs, H.E. (2013). The development of a municipal water conservation and demand management strategy and business plan as required by the Water Services Act: Empirical Study of South Africa. Water SA, 39 (3), 415-422.

Yadav, S.M, Singh, N.P, Shah, K.A, \& Gamit, J.H. (2014). Performance Evaluation of Water Supply Services in Developing Country: A Case Study of Ahmedabad City, KSCE. Journal of Civil Engineering, 18 (7), 1984-1990.

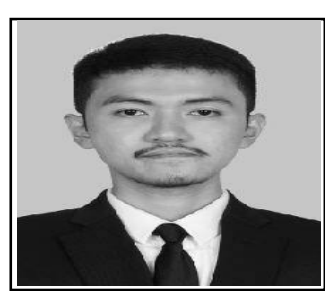

Muhammad Haekal was born in Jakarta Indonesia. Graduated with a Bachelor's degree in Accountancy from Economics and Business Faculty Universitas Pembangunan Nasional Veteran Jakarta, graduated in 2020 and complete.

Praptiningsih was born in Solo, Indonesia. Graduated with a Bachelor's degree in Accountancy from Universitas Pembangunan Nasional veteran Jakarta. Continued his Master degree in Magister Management study program of the Faculty of Economics, Universitas Pembangunan Nasional veteran Jakarta, graduated in 2011 and complete. 